\title{
Why the Bible Cannot and Should Not Be Taken Literally
}

\author{
Randall S. Firestone \\ Department of Philosophy, El Camino College, Torrance, CA, USA \\ Email: Randyfirestone@verizon.net
}

Received 17 June 2014; revised 20 July 2014; accepted 2 August 2014

Copyright (C) 2014 by author and Scientific Research Publishing Inc.

This work is licensed under the Creative Commons Attribution International License (CC BY). http://creativecommons.org/licenses/by/4.0/

(c) (i) Open Access

\section{Abstract}

This paper argues that there are at least five reasons why the claim that the Bible is to be taken literally defies logic or otherwise makes no sense, and why literalists are in no position to claim that they have the only correct view of biblical teachings. First, many words are imprecise and therefore require interpretation, especially to fill in gaps between general words and their application to specific situations. Second, if you are reading an English version of the Bible you are already dealing with the interpretations of the translator since the earliest Bibles were written in other languages. Third, biblical rules have exceptions, and those exceptions are often not explicitly set forth. Fourth, many of the Bible's stories defy logic and our experiences of the world. Fifth, there are sometimes two contrary versions of the same event, so if we take one literally then we cannot take the second one literally. In each of these five cases, there is no literal reading to be found. Furthermore, this paper sets forth three additional reasons why such a literalist claim probably should not be made even if it did not defy logic to make such a claim. These include The Scientific Argument: the Bible contradicts modern science; The Historical Argument: the Bible is historically inaccurate; and The Moral Argument: the Bible violates contemporary moral standards.

\section{Keywords}

Bible, Literal, Cannot Take Bible Literally, Bible Literality, Bible Literalism, Religion, Philosophy of Language, Philosophy of Religion

\section{Introduction}

According to a 2011 Gallup Poll, 30\% of Americans believe that the Bible is the actual word of God and is to be taken literally (Jones, 2011). This is, therefore, the position of tens of millions of Americans. Presumably many, if not most, literalists believe that we merely need to consult the Bible and then the solutions to the moral and 
other problems we face will be unambiguously revealed. Of concern, the belief in a literal reading leaves no room for competing beliefs or understandings of the Bible. All other views are systematically condemned as wrong. This literalism has thus fostered intolerance towards others who hold different interpretations of the biblical texts.

This paper argues that there are at least five reasons why the claim that the Bible is to be taken literally defies logic or otherwise makes no sense, and why the literalists are in no position to claim that they have the only correct view of biblical teachings. Furthermore, this paper will set forth three additional reasons why such a literalist claim probably should not be made even if it did not defy logic to make such a claim.

Interestingly, we find the equivalent type of literalist claim made by those who label themselves strict constructionists of the United States Constitution. Similar to the biblical literalist, the constitutional strict constructionist fails to understand the very nature of words and language. Indeed, many of the points made in this paper apply to a variety of other texts too, not just the Bible.

Although I will be focusing on the Old Testament, the one book that is common to Christianity, Islam, and Judaism, the points I will make could just as well be made with the New Testament or the Koran. In fact, I will at times refer to the New Testament to buttress particular points being made, and to demonstrate that the New Testament suffers from similar challenges ${ }^{1}$.

One further point that should be noted is that most Christians who claim to take the Bible literally do not realize that they actually do not do so. First, according to biblical scholar James Barr, virtually all Christians have failed to follow many of the laws and requirements enunciated in the Old Testament.

But the fact remains: in biblical interpretation, in the handling of purely theological assertions (as distinct from historical or the like), literality runs into difficulties because of consequent inner contradiction, and is thereby forced into some non-literal mode of understanding...

The Jewish law commanded certain specific actions, and prohibited others. Certain birds are "unclean" and may not be eaten (Leviticus 11.13-20; Deuteronomy 14.11-20); a sort of ritual trial is required for a woman suspected of adultery (Numbers 5.11-31); the levirate marriage, an arrangement whereby a brother must take the widow of his deceased brother and produce a child to his name, is commanded (Deuteronomy 25.5-10); and so on.

Within Christianity some elements of the Old Testament law were, at least approximately, taken over (e.g., forbidden decrees of kinship of marriage); others had some sort of analogical continuance (Christian restriction of activities on Sunday had some sort of distant similarity to the Jewish Sabbath); others again, and these surely were the majority, were totally unrepresented in any kind of Christian practice. Yet the Hebrew laws continued to be respected as part of authoritative scripture. The result was a curious mélange of literal and non literal understandings. (emphasis added) (Barr, 1989: p. 418).

The New Testament, too, has laws or rules that virtually all Christians routinely ignore, and thus have not been take literally. Barr explains as follows:

Problems of this kind with ethical commands were not confined to the Old Testament: similar things happened in the New. Jesus' teaching about divorce was commonly put into literal effect, while his prohibition of the swearing of oaths (Matthew 5.33-37) was generally ignored, and was literally observed only by particular groups, notably the Quakers. The express requirement of the Apostolic Council of Acts 15 that Gentile Christians should abstain from the consumption of blood was, apparently, forgotten. The New Testament therefore, at least in its ethical instruction, seemed to produce inequalities of execution similar to those arising in the Old. (Barr, 1989: p. 419).

Additionally, Barr points out that the Bible is supposed to communicate to us the will of God, but the reader is often left with questions as to the purpose and will behind many of God's pronouncements and actions, thus inducing the reader to go beyond the literal words and to add to and creatively interpret the biblical passages. He further claims that the apparent absurdity of some of the Hebrew laws was taken as support for the position that an allegorical meaning, and not a literal one, was intended, and that when it comes to the Bible, "people use the

\footnotetext{
${ }^{1}$ All Old Testament references and quotes in this paper will be from The Torah: A Modern Commentary (Plaut, 1981). All New Testament references and quotes in this paper will be from the Holman Christian Standard Bible, 1999.
} 
term 'literal' not for the meaning that is derived purely and simply from the words themselves, but for the meaning that is most important and authoritative” (Barr, 1989: p. 421). As such, Barr concludes that Christians have distorted the meaning of "literal" in order to claim that they take the Bible literally when in fact they do not do so.

\section{Why the Bible Cannot Be Taken Literally}

This section will address why the Bible cannot be taken literally. Now of course people can say that they are reading the Bible literally, but I will argue that this claim does not logically hold up. It leads one to either hold contradictory views at the same time, which violates the basic laws of logic and reasoning, or it otherwise does not make sense. Therefore, when people claim to take the Bible literally it is in some ways similar to believing that a square can be round. You can claim that a square is round, but if you make such a claim then you do not understand what a square is. It is a nonsensical assertion. Likewise, you can claim that you take the Bible literally, but you will then be claiming the ability to use and understand words and language in a way that cannot be done, or you would have to believe contradictory claims at the same time.

We should note the challenge of understanding what the term "literal" means to the literalist. Barr concludes "that the sense of 'literal' as applied to biblical study, is far from being clear." (Barr, 1989: p. 413). He observes that people who object to taking the Bible literally have in mind, at a minimum, that the words are to be taken as "approximately" conveying correct information, or "relative" to both what is said elsewhere in the Bible and what is known from other sources. I think Barr's portrayal is a good starting point for what I have in mind when I state that the Bible cannot be taken literally.

\subsection{The Interpretation Argument: Filling in the Gaps}

The Bible literalist tends to believe that the Bible can answer all of the relevant and hard questions that one will face in their lives. One merely needs to consult the Bible and read the words there. The assumption is that the words are clear-with plain and obvious meanings which do not require any type of sophisticated analysis or creativity. This section will challenge those beliefs and assumptions, and focus on the numerous gaps that need to be filled in by anyone applying the Bible to their lives. What will emerge is the false sense of security in which literalists have cloaked themselves - false because of the inevitability of having to, at times, actively interpret biblical passages.

While it is true that many simple statements such as "The book is on the desk" can be taken literally in that they have an obvious meaning which requires little if any interpretation, many words, sentences, paragraphs, stories, etc. do not work this way. There is an inherent imprecision and complexity in language that often requires one to go beyond the literal meaning of the words and introduce interpretations which are anything but obvious. Virtually any text, and certainly one as long and complex as the Bible, will need such interpretations. To understand why this is the case, we need to understand what words are and how they work.

Words are symbols. They are used to convey one's thoughts to other people. However, no matter how articulate one is, the listener or reader will not know exactly what is in the mind of the communicator. When I use a word you will usually (if not always) have a different picture or idea in your mind as I have in mine. This is true, in part, because words are often vague, ambiguous, overbroad, general, or otherwise imprecise. To make matters worse, words usually have multiple meanings, and those meanings vary according to the context. This inherent imprecision in words has been noted by some very famous philosophers, such as the $20^{\text {th }}$ Century Austrian philosopher Ludwig Wittgenstein who takes the example of a green leaf to show that each of us would picture its color and shape differently.

So if I am shewn various different leaves and told "This is called a 'leaf'," I get an idea of the shape of a leaf, a picture in my mind-But what does the picture of a leaf look like when it does not shew us any particular shape, but "what is common to all shapes of leaf"? What shade is the "sample in my mind" of the colour green — the sample of what is common to all shades of green (Wittgenstein, 1953: p. 1163).

A green leaf is a concrete object. Abstract ideas, such as justice, charity, friendship, or freedom, tend to be open to an even greater number and range of interpretations. For example, what does someone mean when they say of a wrongdoer that "justice must be served"? What exactly do they have in mind for the punishment? It is anything but clear, and certainly open to many possible interpretations. 
Furthermore, over time we expand and change the meaning of words. This is no great surprise since we are the ones who create language in the first place, and we continue to create-both inventing new words and expanding and changing the definitions of older words. For example, the word "gay" means light-hearted, carefree, and happy. More recently, it also refers to homosexuals, especially male homosexuals.

Wittgenstein explains the somewhat haphazard growth of language by an analogy to the growth of a city:

Ask yourself whether our language is complete; whether it was so before the symbolism of chemistry and the notation of infinitesimal calculus were incorporated into it; for these are, so to speak, suburbs of our language $\cdots$ Our language can be seen as an ancient city: a maze of little streets and squares, of old and new houses, and of houses with additions from various periods; and this surrounded by a mulititude of new boroughs with straight regular streets and uniform houses (Wittgenstein, 1953: p. 1159).

Moreover, languages not only grow and change, but also the meanings of words can be lost over time. For example, Exodus 21:22 states as follows: "When men fight, and one of them pushes a pregnant woman and a miscarriage results, but no other damage ensues, the one responsible shall be fined according as the woman's husband may exact from him, the payment to be based on reckoning." What is "reckoning?" The meaning of the Hebrew word is uncertain, and there is nobody alive from those times to ask. Indeed, the ancient Bibles are going to be difficult to understand today because language and meanings change over time. This is true whether one consults an early Hebrew, Greek, or Aramaic version of the Old Testament. As such, the so-called literalist cannot know what the Bible, an ancient document written in an ancient version of a language, is literally saying.

Additionally, the boundaries of a word are anything but precise. Wittgenstein gives us the example of games, and explains that there is not one thing that is common to all things we call games. Games come in very different types, including board games, card games, ball games, Olympic Games, etc. Wittgenstein concludes as follows: "For how is the concept of a game bounded? What still counts as a game and what no longer does? Can you give the boundary? No.” (Wittgenstein, 1953: p. 1162).

Due to this imprecision in language, the listener or reader is regularly put into the position of having to interpret words which are open to many interpretations. To make matters worse, words must be understood in their context and as part of a document. Further, words must not only be consistent with and cohere with the other words in any given document, but also with our knowledge of many other things. Thus words, sentences, paragraphs, and even books cannot be viewed in an isolated fashion.

Furthermore, the purposes and objectives of words need to be considered, and this is especially true when those words are used to form principles and rules. Additionally, words, principles, and rules are limited and finite, and as such it is difficult to apply them to the almost limitless situations we may face in life. We can say there is a large gap to be filled between the rules and the myriad of specific situations to which the words or rules are to be applied.

Summing up the challenges of words, including rules and principles which are made up of words, we can say that they regularly have a certain generality and imprecision which requires interpretation; words usually have multiple meanings and those meanings change over time; and due to their being finite, words have gaps where they often do not provide clear answers in specific situations ${ }^{2}$. The Bible is not exempt from these challenges.

Let us take two examples from the Bible's 10 Commandments to demonstrate the imprecision of many words, and the gap problem of applying those words to specific situations. The 4th Commandment states as follows: "Remember the Sabbath Day and keep it holy. Six days you shall labor and do all your work, but the seventh day is a Sabbath of the Lord your God. You shall not do any work."

Let us put ourselves in the position of someone who claims to take the Bible literally, and ask ourselves what constitutes work? Does shoveling snow from your driveway constitute work? Is driving your car to the beach work? Does preparing and cooking dinner constitute work? What about if you are a psychologist and on the Sabbath you give free psychological counseling to a friend in need? What are the literal answers to these questions?

\footnotetext{
${ }^{2}$ There is a parallel between a court's interpretation and application of laws, which are made up of words, and our point about the interpretation needed regarding the words of the Bible. Courts must use their discretion when applying the laws to specific cases because of the imprecision of general terms, and also due to gaps in laws and language. This was well-put by legal scholar Jules Coleman who stated the following:
}

Often overlooked is the fact that there are two distinct arguments for discretion: One relies on the controversial nature of penumbra cases involving general terms; the other relies on finiteness of legal standards. The first argument is actually rooted in a theory of language; the second, which would survive a rejection of that theory, relies on gaps in the law (Coleman, 1982: p. 130, note 9). 
The answer is that there is no literal answer. Neither cars nor shoveling snow nor cooking dinner nor giving psychological counseling is mentioned in the $4^{\text {th }}$ Commandment. "Work" is an imprecise and general term, and there is a gap between the general word "work" and the myriad of situations to which we might apply it. The Old Testament could certainly not address anything regarding cars because automobiles were not yet invented. Furthermore, I do not believe that the Bible specifically addresses any of these situations. Therefore any answers to these questions are not literal. If these specific situations are not mentioned in the Bible, then in these cases there is no way to be sure what constitutes work. Moreover, the same action might constitute work in one context and not in another-as playing tennis is a profession for some and a hobby for most. Indeed, people can reasonably have very different interpretations as to what constitutes work. Cooking dinner might be work to one person, while it is a pleasurable pastime to another.

What is especially interesting is that most of us would probably say that none of the above examples would constitute work. However, many Orthodox Jews consider some or all of these situations as constituting work, and therefore forbidden by the Bible. They are of course entitled to live their lives according to their own interpretations, but that does not mean that they are taking the Bible literally and others are not. These situations need interpretation because they are not spelled out in the Bible.

As a second example, let us look at the $5^{\text {th }}$ Commandment: "Honor your father and your mother." If you are a literalist, what is the literal reading of this commandment in the following situations: Do you dishonor your parents if you do not listen to their advice? Must you go into the profession that your father or mother wants you to pursue? Must your parents approve whom you marry? Is there a point that you no longer need to follow the advice of your parents, such as when you are 18 years old, or you marry and start your own family?

If you take the Bible literally, what are the answers to these questions? Based on this passage alone, there is no literal reading because the $5^{\text {th }}$ Commandment does not address any of these specific situations. The term "honor" is vague, general, and imprecise, and there is a gap regarding how to apply the term to various specific situations. Any answer you arrive at is your interpretation unless you find a similar situation discussed elsewhere in the Bible, and even then you must interpret and analyze whether there are any relevant differences between the situation in the Bible and your current situation.

The $20^{\text {th }}$ century French philosopher Jean-Paul Sartre tells us about one of his students who sought his advice during World War II. The student's father had abandoned the family and starting collaborating with the Nazis, and his older brother had been killed by the Nazis. The student wanted to do his part and join the French forces who were fighting the Nazis, but he knew that if he were killed then his mother would have lost her entire immediate family, and would likely be emotionally devastated for the rest of her life. What should he do? Sartre explains why the Bible would be of limited help in this situation because its general principles are imprecise and there is a gap as to how they should be applied to the situation at hand.

And, at the same time, he was hesitating between two kinds of morality; on the one side the morality of sympathy, of personal devotion and, on the other side, a morality of wider scope, but of more debatable validity. He had to choose between those two. What could help him to choose? Could the Christian doctrine? No. Christian doctrine says: Act with charity, love your neighbor, deny yourself for others, choose the way which is the hardest, and so forth. But which is the harder road? To whom does one owe the more brotherly love, the patriot or the mother? Which is the more useful aim, the general one of fighting in and for the whole community, or the precise aim of helping one particular person to live? Who can give an answer to that a priori? No one. Nor is it given in any ethical scripture. (Sartre, 1949: pp. 212-213).

Indeed, the claim that one takes the Bible literally would do nothing to help Sartre's student resolve his situation. There was no literal answer to his moral dilemma. There was a gap between biblical ethical principles and the specific situation.

Those who say they take the Bible literally or claim to be Constitutional strict constructionists commit what I call the Fallacy of Literal Reading or Strict Construction. Because both the Constitution and religious scriptures are made up of words, they need to be interpreted. Saying that you take it literally tells us nothing unless there is only one way to interpret the words. Usually there are many ways. As such, any one view is only one of many possible interpretations.

It is interesting to note that both Judaism and Christianity have a long history of interpreting the Bible, and have not claimed to take it literally. In Judaism several ancient books, including the Mishnah and Gemara which together form the Talmud, consist of various Rabbis' interpretations of the Bible. Rabbinic interpretation is still 
actively practiced in Judaism today.

Likewise, historically, Christianity has understood that the Bible requires interpretation. For one, Jesus often talked in parables that needed interpretation. Second, 2 Corinthians 3:6 states "He has made us competent to be ministers of a new covenant, not of the letter, but of the Spirit; for the letter kills, but the Spirit produces life.” This passage seems to call out for interpretation over inflexible readings and practices. Third, Saint Augustine (354-430 A.D.) said in his commentary on the Book of Genesis "If it happens that the authority of Sacred Scripture is set in opposition to clear and certain reasoning, this must mean that the person who interprets Scripture does not understand it correctly." (Saint Augustine ${ }^{3}$ ). More recently, Pope John Paul II (1920-2005) made it clear that the Bible should be interpreted in a way that it does not contradict modern science (Pope John Paul II, 1992 \& 1996: pp. 502-507).

In recognition of these points, some literalists have attempted to portray their position as being somewhat more moderate than perhaps I have depicted it. For instance, the Chicago Statement on biblical Inerrancy reads as follows:

WE AFFIRM the necessity of interpreting the Bible according to its literal, or normal, sense. The literal sense is the grammatical-historical sense, that is, the meaning which the writer expressed. Interpretation according to the literal sense will take account of all figures of speech and literary forms found in the text. WE DENY the legitimacy of any approach to Scripture that attributes to it meaning which the literal sense does not support (Chicago Statement, 1997).

So the Chicago Statement on Biblical Inerrancy defines literal as interpreting the Bible in a "normal sense" and according to the expressed intention of the writer, which in this case would seem to be God. The intentions of God as expressed in the Bible, however, are often anything but clear. Barr expounds on this problem:

The bible is supposed to communicate to us the will of God; such is a normal assumption of all kinds of Judaism and Christianity. But much of it, by strict literal interpretation, does not tell us of his intentions or his will $\cdots$ What did God think about Abraham's allowing his wife to be taken into Pharaoh's house (Genesis 12.14-20)? Taken literally: no answer. What was God's intention in relation to the elaborate story of Absalom's rebellion against David (2 Samuel 14-19)? No answer. That God created heaven and earth in seven days is, literally, clear, but why did he do it in just this way? Why in seven days, when nine might have been appropriate $\cdots$ or twelve, or perhaps forty-nine, which would have fitted the jubilee just as seven fits the week? What was God's purpose in doing it in just this way? The text, taken literally, offers no answer. Why did Jesus, not only occasionally but repeatedly, forbid his disciples to make known that he had been identified as Son of God (e.g., Mark 3.12)? * - On a literal basis, again, no answer (Barr, 1989: p. 424).

Moreover, the Chicago Statement concedes that "literal" involves at least a limited kind of interpretation, but if it involves interpreting it seems not to be literal unless the statement, given its context, can be reasonably interpreted in only one way. The Bible, however, is littered with many complex statements, including moral principles and rules. The "normal sense" of such principles does little to help one apply the Bible to real life situations. Additionally, the Chicago Statement is unclear and itself requires interpretation about where one would draw the line between permissible and impermissible interpretations.

Indeed, neither the Bible nor any complex document can be taken literally because words by their nature need interpretation, and most words are open to a variety of different interpretations due to their lack of specificity, multiple meanings, the many contexts in which they are used, or the numerous situations to which they are applied. The finite books of the Bible cannot provide us with answers to the almost infinite situations in which we might find ourselves. Accordingly, those who say they take the Bible literally are not making sense. They do not understand what words are and how they work. They must interpret the words and situations in the Bible, just as the rest of us do. The Bible cannot be taken literally because, like every other document, and especially long and complex ones, the Bible's words, sentences, paragraphs, and books require interpretation due to the nature of words themselves.

\subsection{The Translation Argument}

In what language were the original Bibles written? The oldest version of the Old Testament found to date was

${ }^{3}$ Saint Augustine, Espitula 143, n. 7 PL 33, col. 588, and as quoted by Pope John Paul. In M. Rea, \& L. Pojman (Eds.), Philosophy of Religion: An Anthology (7th ed., p. 504). Stamford: Cengage Learning. 
written in Hebrew. The next oldest is a Greek version. The third oldest was written in Aramaic. The fourth and fifth oldest versions of the Old Testament were written in Syrian and Latin. Experts claim that the Syrian and Latin versions are translations from the original Hebrew versions. The Greek and Aramaic texts, however, do not appear to be translations from the first Hebrew Bibles. In other words, though very similar to the Hebrew version, they are their own originals and have some clear differences from the Hebrew version.

Many Americans claim to take the Bible literally. There are some conspicuous problems with this claim since most of them are reading an English translation of one of these earlier versions. The first issue is which version do they claim to take literally? Each version is different. Even if you could take one version literally, you would then not be taking the other versions literally because they have differences.

Second, let's say that you spoke Hebrew and were using the original Hebrew version. You would still need to interpret the meaning of ancient Hebrew words and phrases, which are somewhat different than present-day Hebrew. To understand this, just read any of the writings of William Shakespeare who lived from 1564 to 1616, or Sir Francis Bacon who lived from 1561-1626. Although their works were written in English only about 400 years ago, they are difficult for both Americans and Englishmen to understand today. The various portions of the Old Testament were written between 2000 and 3000 years ago-which is going more than five times as far back in time as when Shakespeare lived. Think how much has changed since then. James Barr explains that we may think we know the meaning of a word, but our current understanding may be quite different from the ancient meaning.

If "what we call 'literal' usage is accustomed usage," then most people interested in the Bible will be guided by the English usage of their own modern religious environment $\cdots$ People just assume that they know the meanings of terms like "covenant," "kill," "slave,” "redeem," "holy,” "repent," and a host of others. They read into them modern meanings, most commonly meanings derived from recent preaching traditions and from the modern church cultures in general (Barr, 1989: pp. 421-422).

Third, let us assume that you speak Hebrew and are looking at a Hebrew version of the Bible. Let us further assume that you have a pretty good idea about what is meant by the ancient Hebrew. It is now your task to translate the Bible into English. Anybody who speaks more than one language knows that translations are not perfect. Words and sentences cannot always be neatly translated into another language. Sometimes there is no word that fits the second language well. All translators must first interpret the passages, and then do the best they can to give the reader of the second language the flavor of the original passage. The translator must also consider the context of each word, sentence, and paragraph, and how it fits with the entire text. That is why there are different translations of the Bible. Some translators try to translate each word, but these translations often make little sense in the new language. Other translators try to give the reader the "feel" or intent of the original version but are less true to the actual words used in the original language. Whatever the translation settled upon, the translator is giving his best interpretation of the original text.

For example, the Hebrew word "she'ol" is sometimes translated as "hell," but can also be translated as "abode of the dead.” These two definitions portray very different meanings, so the translator's choice is very important. In the following analysis of the term, Jeff Benner explains the problem as follows:

In the Old Testament, the Hebrew word she'ol is translated as either "hell" or "grave $\ldots$ " The word she'ol is the place where one goes when they die. The question is, did they understand this to be simply the grave where one is buried or another place one goes after they die--the underworld? This is a difficult question for one to answer, because the Hebrew Bible never really defines she'ol $\cdots$ The Ancient Hebrews did not know where, or even what, she'ol was. To them it was an "unknown" place, hence its relationship to sha' $a$ l meaning “unknown.” (Benner, 2007: pp. 28-29).

Indeed, the reader of an English version of the Old Testament must interpret what is already the translator's interpretation. Even if the translated English words seem clear to the reader, if different words had been chosen for the translation then different understandings of the text would follow.

A more humorous example regarding a translator's choice of words comes from the story of Cain and Abel. God favored Abel's offering to Him of a sheep over Cain's offering of only vegetables or fruit. The translated text I use states as follows: "And the Lord said to Cain: 'Why are you distressed, and why is your face fallen?'” (Genesis 4:6) A literal reading would mean that Cain's face actually fell, but this hardly seems the intent of the passage. The translator could have more accurately portrayed the meaning of the text with a translation such as "Why does your face display such distraught?" 
Let us take two more examples. First, the Sixth Commandment is often translated "You shall not kill.” With this translation you might think that Judaism and Christianity call for pacifism. In fact, many of the early Christians were pacifists, and were persecuted by the Roman Empire because they were viewed as disloyal subjects who would not fight for the Roman Empire. However, some biblical scholars have claimed that the Sixth Commandment should be translated as follows: "You shall not murder." The word "murder" does not mean the same thing as "kill." Murder is a particular type of killing-the killing of an innocent person. So to forbid murder would still permit the killing of people who were not innocent, such as those wrongfully attacking and trying to kill you or your loved ones. How this passage is translated can affect what you think is meant by the passage.

Second, according to most of the English translations of the Bible, the universe is about 6000 years old. However, this figure is based in part on the assumption that each day of the first six days of creation correspond to a 24-hour day. However, some followers of the Bible have claimed that the first six days of creation are not necessarily 24 hour days. Why not? Since the sun was not created until the $4^{\text {th }}$ day, the first three so-called days could not be a day based on the rising and setting of the sun, and therefore might not correspond to 24 hours. So what is translated as a "day" could be any number of hours, years, days, or even millions or billions of years. For those first three "days" the translator could have chosen to translate the word "day" with a different word to recognize this discrepancy-in which case the age of the universe according to the Bible could be vastly different than it is currently interpreted to be.

We can see that there are all sorts of problems presented by the fact that the Bible was written in languages other than English. For an English-speaking American to rely on an English version of the Bible and to also claim that they take the Bible literally is to make a nonsensical claim. The English speaker must interpret words that have already been interpreted by someone else, the translator-words that have been translated into English in a very inexact and imprecise way. Even if there were a literal reading, which I have already argued often does not exist, if you do not speak the original language then you could not possibly know the literal meaning of the original version. You are dependent on the judgments and interpretations of the translator. Of course, this problem is not unique to the Bible. This is true with all writings translated from another language.

\subsection{The Exceptions Argument: The Fallacy of Accident}

The fallacy known as "Accident" occurs when someone applies a rule, law, or principle as if it had no exceptions. It is falsely presumed that the rule is always correct in all circumstances. Most rules, however, have exceptions. Each rule is meant to apply to cases under certain conditions, but when those conditions are not met then the rule is inapplicable. It would be far too cumbersome to outline all exceptions to a rule when stating that rule. One could fill a whole book with the exceptions to most rules. Think of the rule which forbids lying. Although this is a good general rule, we could think of a vast variety of exceptions, such as lying to a tyrant in order to save an innocent person. Certainly not all situations and exceptions are mentioned in simple and general rules, and there are times when the general rule is inapplicable.

Let us again take the example from one of the Ten Commandments: “Thou shall not kill.” Taken literally, this rule would make it immoral to kill someone, even in self-defense. However other passages in the Old Testament seem to allow for the killing of another person in a variety of situations. If that is so, then either the $6^{\text {th }}$ Commandment cannot be taken literally, or the other passages that allow one to kill another person cannot be taken literally. Indeed, we can see here that it is not helpful for someone to claim that he or she takes the Bible literally. The biblical prohibition against killing needs to be read in the broader context of the many books of the Bible-and those books call for exceptions to the sparsely outlined general rule stated in the Commandment.

Indeed, one must interpret the meaning behind the rules and try to make sense of the Old Testament as a whole. However, once one does this, he is not taking the Bible literally. Rather, he is interpreting the passages, realizing that the rules outlined in the Bible cannot be inclusive of every possible scenario, and that there are exceptions to language and rules even though those rules might appear clear when taken by themselves and out of context.

This principle is demonstrated by an ancient Buddhist story. Two monks were traveling together, an older monk and a younger monk. They noticed a young woman at the edge of a stream, afraid to cross. The older monk picked her up, carried her across the stream and put her down safely on the other side. The younger monk was shocked, but he didn't say anything until their journey was over. "Why did you carry that woman across the stream? Monks aren't supposed to touch any member of the opposite sex" said the younger monk. The older monk replied "I left her at the edge of the river, are you still carrying her?" Indeed, the older monk understood 
the purpose of the prohibition against touching a woman, and also understood that this was the right time to make an exception and serve the greater good. He did not take the prohibition literally, but rather understood that there were unstated exceptions to the general prohibition.

\subsection{The Common Sense Argument}

Let us examine a portion of the biblical passage about Cain and Abel, the two sons of Adam and Eve.

Now the man knew his wife Eve, and she conceived and bore Cain, saying, "I have gained a male child with the help of the Lord.” She then bore his brother Abel. Abel became a keeper of sheep, and Cain became a tiller of the soil $\cdots$ when they were in the field, Cain set upon his brother Abel and killed him *. Cain left the presence of the Lord and settled in the land of Nod, east of Eden. Cain knew his wife, and she conceived and bore Enoch. (Genesis 4:1-2, 4:8, 4:16-17).

This passage should be very troubling to the reader. Adam and Eve, the first two people on earth, originally had only two children, two boys named Cain and Abel, and they never had a daughter. (Later, Adam and Eve did have another son Seth: "When Adam had lived 130 years, he begot a son in his likeness after his image, and he named him Seth.” (Genesis 5:3)). How could the human race continue? There are no women for either Cain or Abel to impregnate. This is particularly puzzling since the Bible has a very detailed genealogy of offspring. For example, following the passage about Cain's banishment, the recitation of that genealogy begins. "To Enoch was born Irad, and Irad begot Mehujael, and Mehujael begot Methusael, and Methusael begot Lamech.” (Genesis 4:18). In the immediate sentences that follow, several more generations of people are set forth. So how did only boys continue the human race? If you take the Bible literally, you have a big problem: You have no explanation of how the human race could continue past the second generation.

After Cain is banished from his home, the very next passage in the Bible states that he is married and has a son Enoch. However, there is no explanation of where Cain's wife came from. Did she just appear out of thin air? Again, this seems strange in view of the detailed genealogy.

In fact, when Cain is banished he has the following conversation with God:

Cain said to the Lord, "My punishment is too great to bear! Since you have banished me this day from the soil, and I must avoid your presence and become a restless wanderer on earth—anyone who meets me may

kill me.” The Lord said to him, "I promise, if anyone kills Cain, sevenfold vengeance shall be taken on him." (Genesis 4:13-15).

From where did all these people come that Cain is worried about killing him? If we read the Bible literally, we have at this point only three people on earth, Adam, Eve, and Cain. Abel has been killed, and Seth not yet born. If Cain is sent away from his parents, then there would be nobody else on the earth. Hence Cain's fear and his reference to other people who might kill him would make no sense, nor would God's response to him. Of course we can make some sense of these passages with some creativity and interpretation, but not by taking the words literally. The person who claims to take the Bible literally has a story that defies logic-unless one reads more into the passages than are there, and if they do so they are adding their interpretation, which is not taking the Bible literally.

We could take many other examples. For example, Jonah was supposedly in a big fish's belly for three days and three nights, and then was vomited out onto dry land? (Jonah 2:1-11). Anatomically, this is impossible. There is no mention in the Bible that the inside of the fish or whale was altered to allow Jonah to survive in it. How could the whale's digestive enzymes not kill Jonah? In our reading of the story about Jonah and the whale we could add to this passage that God altered the whale's inner body to allow this to happen, but if we do this we are adding and interpreting, not taking the Bible literally. Literally, the passage makes no sense without the insertion of additional information and therefore interpretation.

Our last example is from Noah and the Ark. How could one man build an ark so big that it could hold a pair of all the species in the world? To date, scientists have identified 1.9 million species of plants and animals, but this is only a small percentage of the total number of species in the world-which has been estimated by scientists as more than 11 million. As to animals, there have been over 5000 mammals found (not even including domesticated animals), more than 62,000 vertebrates identified, and more than 1.3 million invertebrate animals classified (Wikipedia, 2014: Global Biodiversity). Of course, it is true that neither plant species nor all insect species 
nor fish species would be expected to travel in the Ark. However, even if we only include non-insect land animal species, it would still encompass an enormous number of animals, including "birds of every kind, cattle of every kind, every kind of creeping animal on earth $\cdots$ ” (Genesis 6:20) It strains credibility to believe that Noah built an arc large enough to hold all of these species of animals.

But what is even more unbelievable is that Noah captured all of the animals and got them onto the ark, was able to separate the dangerous ones from the other animals, and was able to feed and care for all of them. To capture the animals would literally require an army of men, and a great amount of time. One would have to travel to all parts of the world to obtain species that occur on only one continent, an impossible task for those times. Not only would it be difficult to travel to Asia to obtain giant pandas, snow leopards, and tigers, but at that time it was impossible to travel from the Middle East all the way to South America, the only continent where the llama, armadillo, chinchilla, and flamingo live. Noah was given an impossible task, so it is unbelievable that "Noah did so; just as God commanded him." (Genesis 6:22) We cannot take this story literally unless we are willing to dispense with our common sense.

\subsection{The Contradiction Argument: Two Stories of the Same Event}

Biblical scholars have noticed that there are many instances in the Bible where there are two similar yet clearly different versions of what seem to be the same event. If this is true, then if we take one of the stories as literally true then the second version cannot be taken literally.

For example, many people do not realize that there are two different stories about the creation of the universe in Genesis. We will focus on the sixth day of creation. The first version in Genesis states as follows:

God said, "Let the earth bring forth every kind of living creatures: cattle, creeping things, and wild beasts of every kind.” And it was so. God made wild beasts of every kind and cattle of every kind, and all kinds of creeping things of the earth. And God saw that this was good. And God said, "Let us make man in our image, after our likeness. They shall rule the fish of the sea, the birds of the sky, the cattle, the whole earth, and all the creeping things that creep on earth.” And God created man in His image, in the image of God He created him; male and female He created them (Genesis 1:24-27).

So what is the order of creation here? First God created the animals, and then he created man and woman, apparently creating man and woman at the same time. Now let us look at the more familiar second version that appears just a little later in Genesis.

The Lord God formed man from the dust of the earth. He blew into his nostrils the breath of life, and man became a living being... The Lord God said, "It is not good for man to be alone; I will make a fitting helper for him.” And the Lord God formed out of the earth all of the wild beasts and all of the birds of the sky, and brought them to the man to see what he would call them; and whatever the man called each living creature, that would be its name. And the man gave names to all the cattle and to the birds of the sky and to all the wild beasts; but for Adam no fitting helper was found. So the Lord God cast a deep sleep upon the man; and, while he slept, He took one of his ribs and closed up the flesh at that spot. And the Lord God fashioned the rib that He had taken from the man into a woman; and he brought her to the man (Genesis 2:7, 18-22).

In the second version, God first created man, then the animals, and lastly woman. This differs from the first version where the animals came first before man, and as we noticed arguably man and woman were then formed at the same time after the animals. Clearly, these versions are different, so if you take one literally you cannot take the other one literally.

A second example of contradictory stories is regarding the death of Aaron, Moses' brother. In Numbers 33:38 (See also Numbers 20:22-29) the Bible says that "Aaron the priest ascended Mount Hor at the command of the LORD, and died there..." while in Deuteronomy 10:6 it says that "the Israelites marched to Moserah. Aaron died there and was buried there $\cdots$ " If you take the first passage literally, Aaron died at Mount Hor, but then the second passage cannot be taken literally that says Aaron died and was buried at Moserah.

Our third example returns us to the biblical story of Noah and the flood. According to Genesis 6:19 God ordered Noah to bring "of all that lives, of all flesh, you shall take two of each into the ark to keep alive with you; they shall be male and female." A little later in Genesis 7:2-3 it states "of every clean animal you shall take seven pairs, males and their mates, and of every animal which is not clean, two, a male and its mate.” There is no 
mention of seven pairs of animals in the first version. In order to make the passages consistent, we could interpret the first passage as only referring to unclean animals. If we do so, however, we are interpreting, not taking the Bible literally. The words in the first version say "of all lives, of all flesh.” Taken literally, this would include both clean and unclean animals. The two versions can only be reconciled, if at all, with interpretation.

A fourth example is a rather detailed story which appears in Genesis 12:10-20 about when Abraham went into Egypt and deceitfully told Pharaoh that Sarah was his sister when in fact Sarah was Abraham's wife. This story seems to be retold in Genesis 20:1-7 with some significant variations. In the second version, Abraham's deception takes place in the land of Gerar instead of in Egypt and Abraham deceives King Abimelech instead of Pharaoh. Now we could choose to believe that Abraham pulled the same stunt twice in different places, but the text never indicates that Abraham had done this before, or that Abraham had failed to learn any lessons from his earlier actions. It seems likely that these are two versions of only one event. If so, then if we take one story to be literally true, then the other story cannot be. If we choose, on the other hand, to believe that Abraham lied to two different rulers then we will avoid having contradicting stories, but we would be interpreting the events as being separate even though they appear so similar and there is no acknowledgement that the deception was taking place for a second time.

The New Testament, too, is not immune from discrepancies between its different books. For example, there are at least 4 different versions of the precise words that appear on a sign put over Jesus after he is crucified (Compare Matthew 27:37, Mark 15:26, Luke 23:38, John 19:19); There are competing versions for who was Jesus' $1^{\text {st }}$ Apostle and the subsequent order of the Apostles who next joined and followed Jesus (Compare Luke 5:1-10 and John 1:35-45); There are different stories of the fig tree (See Mark 11:12-26, and Luke 13:6-8); In two versions of the parable of the Vineyard Owner some of the master's slaves are killed (Matthew 21:33-36, Mark 12:1-6) while a third version states that they were not killed, but rather all were only beaten (Luke 20:9-12); Jesus' last words vary in different books (See Mark 15:34 and Matthew 27:46 vs. Luke 23:46); In one book Jesus seems to have been crucified on the day of preparation for Passover (John 13:1 and 19:13-16), but in the other books he is crucified after the Passover dinner. (See for example Matthew 26:17-27:50); lastly, there are various versions about who went to the tomb to see Jesus after the crucifixion, and who actually saw Jesus thereafter (Compare John 20:1-20; Matthew 28:1-10; Mark 16:1-10; and Luke 24:1-24).

Malcolm Murray points out some further discrepancies in both the Old and New Testaments-including discrepancies regarding our moral duties:

The ark is said to have contained two tablets given to Moses and "nothing else" (1 Kings 8:9), yet it also contained manna and Aaron's rod that had "budded" (Heb. 9:4). Those that seek God shall find Him (Prov. 8:17, Matt. 7:8, Luke 11:8-10), yet elsewhere it is admitted that many will not find God even if they seek Him (Ps. 18:41, Prov. 1:28, Lev. 3:8, 3:44, Amos 8:12, Luke 13:24). Apart from one ram, what is the proper sacrifice to God during the new moon? Two young bullocks and seven lambs (Num. 28:11). One young bullock and six rams (Ezek. 46:6). Should we rejoice when our enemies suffer? Yes (Ps. 18:10). No (Prov. 24:17). Can a divorced woman remarry? Yes (Deut. 24:1-2). No (Luke 16:18). Is it okay for a theist to marry an atheist? Yes (1 Cor. 7:12-14). No (Cor. 6:14-17). Is long hair on men good? Yes (Num. 6:5, Judges 13:5, 1 Sam. 1:11). No (1 Cor. 11:44) (Murray, 2010: p. 47).

James Barr presents us with additional biblical contradictions:

Theological statements of scripture about God, if all taken literally, lead to mutual contradictions, which are usually overcome only by abandoning the literal level of interpretation $\cdots$ According to St. Paul, man is justified by faith, and not by works; but St. James avers that "by works a man is justified, and not by faith only" (James 2.24). God 'is not a man that he should repent," we are told in 1 Samuel 15.29: that is, unlike human beings, God does not change his mind: but elsewhere the Old Testament tells us repeatedly of God's changing of his mind, the most notable being his regret that he had created humanity at all, Gen 6.6. Taken literally, these pairs of sayings appear to produce contradictions: Man is justified by faith, no he isn't, he is justified by works; God does not change his mind, yes he does, several times in central biblical themes. If one sticks to pure literality these are insuperable contradictions (Barr, 1989: p. 417).

Barr further points out that contradictions in the biblical texts can appear by the silence or absence in some books of important stories told in other books. For example, the virgin birth story is "clear in Matthew, muted in Luke, and literally absent from Mark and John...” (Barr, 1989: p. 423). 
Indeed, the many contradictions both within and between the books of the Old and New Testament preclude one from being able to logically claim that they take the Bible literally. If they take one of the stories, claims, or laws/rules literally, then they cannot take the competing ones literally.

I have set forth five reasons why I believe that the Bible cannot be taken literally. First, many words are imprecise and therefore require interpretation, especially to fill in gaps between general words and their application to specific situations. Second, if you are reading an English version of the Bible you are already dealing with the interpretations of the translator since the earliest Bibles were written in other languages. Third, biblical rules have exceptions, and those exceptions are often not explicitly set forth. Fourth, many of the Bible's stories defy logic and our experiences of the world. Fifth, there are sometimes two contrary versions of the same event, so if we take one literally then we cannot take the second one literally. In each of these five cases, there is no literal reading to be found.

\section{Why the Bible Should Not Be Taken Literally}

It can be argued that there are other reasons not to take the Bible literally. These three additional reasons fit within the category of why the Bible "should not" be taken literally, as opposed to "cannot." In these instances, it is not nonsensical to take the Bible literally, but there are good reasons not to do so.

\subsection{The Scientific Argument: The Bible Contradicts Modern Science}

The words of the Bible are usually translated and understood in ways that contradict modern science. Specifically, the Bible's claim in Genesis is that the universe is about 6000 years old, not the more than 13 billion years old which scientists agree that it is. The Bible further states that everything, including the stars, the earth, and all the plants and animals on earth were created by God in six days, while science tells us that our sun and earth were not created until billions of years after the big bang, and that it took many more billions of years for the plants and animals to come into existence. Moreover, a literal reading of the Bible contradicts evolution when it states that on the sixth day all of the species, including human beings, were created. Scientists, on the contrary, tell us that our species, Homo sapiens, are relatively recent arrivals on earth, and that, for instance, the dinosaurs were here millions of years before we were.

Because science is based on evidence and these biblical claims are contrary to the evidence, many people believe that the Bible should not be taken literally. This conflict between the words of the Bible and the findings of science was noted by Pope John Paul II (1920-2005) who made it clear that when there is such a conflict, scripture should be interpreted in such a way as to be consistent with accepted scientific findings. This appreciation of science caused the Pope to recognize evolution and to interpret scripture accordingly—reaffirming the view that the Bible is not to be taken literally. The Pope said as follows:

In order to mark out the limits of their proper fields, theologians and those working on the exegesis of the Scripture need to be well informed regarding the results of the latest scientific research $\cdots$ Today $\cdots$ some new findings lead us toward the recognition of evolution as more than an hypothesis. (Pope John Paul II, 1996: p. 505).

\subsection{The Historical Argument: The Bible Is Historically Inaccurate}

We have seen there are numerous contradictions regarding stories described in both the Old and New Testaments, so if one story is accurately portrayed then the competing story must necessarily be historically inaccurate. Likewise, we have looked at several passages and stories which defy common sense and therefore provide us with additional examples of likely historical inaccuracies. These historical inaccuracies fit into our earlier reasons for why the Bible cannot be taken literally. There are, however, additional reasons for suspecting that other biblical stories never happened, and as such provide a reason why one should not take the Bible literally, even if it were possible that those stories occurred.

For example, historians have noticed that many stories in the Bible seem to be a retelling of older stories from earlier legends. For example, the story in the Old Testament of Moses' birth seems strikingly similar to the much earlier story of the King of Sargon, which dates to the third millennium B.C. The Bible account is as follows:

The woman conceived and bore a son; and when she saw how beautiful he was, she hid him for three months. When she could hide him no more, she got a wicker basket for him and caulked it with bitumen 
and pitch. She put the child into it and placed it among the reeds by the bank of the Nile. And his sister stationed herself at a distance, to learn what would befall him. The daughter of Pharaoh came down to bathe in the Nile, while her maidens walked along the Nile. She spied the basket among the reeds and sent her slave girl to fetch it. When she opened it, she saw that it was a child, a boy crying $\cdots$ the woman took the child and nursed it. When the child grew up, she brought it to Pharaoh's daughter, who made him her son. She named him Moses, explaining, "I drew him out of the water." (Exodus 2:2-6, 9-10).

Here is the earlier story of Sargon as set forth on Neo-Babylonian tablets:

Sargon, might King of Akkad, am I. My mother was of mixed blood; I never knew my father... My city is Azupiranu, on the banks of the Euphrates. My mother conceived me and she secretly bore me. She put me into a basket of rushes, and sealed its lid with tar. She cast me into the river which did not drown me. The river swept me to Akiki, the drawer of water. Akiki, the drawer of water scooped me up in his pitcher. Akiki the drawer of water raised me as his son (Colless, 2013).

Although these stories are not identical, their similarities are hard to ignore. In each case the mother had a baby in secret, had to let the baby go, put the baby into a basket that was sealed with tar, sent the baby adrift into a river, and the baby was discovered by the person who ended up becoming his foster parent. Both stories involve babies that would become leaders. It is such an unusual story involving a leader that one has to question if not suspect that the biblical story was borrowed from this earlier story, and is not what really occurred.

Likewise, the New Testament's claim of the miraculous virgin conception of Jesus appears borrowed from earlier religious traditions from around the world. The following are some of the numerous examples of Gods who were the result of virgin births: The Egyptian God Horus, The Aztec God Huitzilopochtli, the Greek God Erechtheus, the Roman God Mars, and according to a famous Chinese myth, Qi was conceived when his mother stepped in a giant footprint left by the supreme diety Shangdi (Gannon, 2013).

Second, not only do some of the stories in the Bible seem to be borrowed from earlier legends or myths, but there is a real question as to whether some of the major occurrences in the Bible ever occurred. For example, recent scholars have begun to question whether the Jews were actually ever slaves in Egypt, and whether the Jews really wandered in the desert for 40 years. According to Exodus 12:40, the Israelites were slaves in Egypt for 430 years. In spite of this, there is no archaeological or documentary evidence outside of the Bible to verify this. As stated by two archaeologists:

We have no clue, not even a single word, about the early Israelites in Egypt: neither in monumental inscriptions on the walls of temples, nor in tomb inscriptions, nor in papyri. Israel is absent-as a possible foe of

Egypt, as a friend, or as an enslaved nation (Finkelstein \& Silberman, 2001: p. 60).

\subsection{The Moral Argument: The Bible Violates Contemporary Morality}

The last reason we will explore that supports the position that the Bible should not be taken literally has to do with the numerous passages that paint God to be vengeful or immoral when viewed from contemporary moral standards. Throughout the Bible God commands or sanctions the enslavement or killing of whole groups of people, even innocent women and children, or those people who transgress God's commandments, even when those transgressions would not seem to warrant the ultimate punishment of death, such as insulting one's parents, or working on the Sabbath by gathering wood for a fire. Here are just a few passages that many people find disturbing. (All underlines for emphasis are my own.)

You shall faithfully observe my laws; I the LORD make you holy. If any man insults his father or his mother, he shall be put to death $\cdots$ If a man commits adultery with a married woman, committing adultery with his neighbor's wife, the adulterer and adulteress shall be put to death $\cdots$ If a man lies with a male as one lies with a woman, the two of them have done an abhorrent thing; they shall be put to death (Leviticus 20:8-10, 13).

Once, when the Israelites were in the wilderness, they came upon a man gathering wood on the Sabbath day *. Then the Lord said to Moses, "The man shall be put to death; the whole community shall pelt him with stones outside the camp." So the whole community took him outside the camp and stoned him to death—as the LORD had commanded Moses (Numbers 15:32, 35-36). 
When the LORD your God brings you to the land that you are about to invade and occupy, and He dislodges many nations before you $\cdots$ you must doom them to destruction: grant them no terms and give them no quarter $\cdots$ You shall destroy all the peoples that the LORD your God delivers to you, showing them no pity (Deuteronomy 7:1-2,16).

If your brother, your own mother's son, or your son or daughter, or the wife of your bosom, or your closest friends entices you in secret, saying, "Come let us worship other gods"... do not assent or give heed to him. Show him no pity or compassion, and do not shield him; but take his life $\cdots$ Stone him to death, for he sought to make you stray from the LORD your God.” (Deuteronomy 13:7, 9-11).

The Lord spoke to Moses saying, "Avenge the Israelite people on the Midianites $\cdots$ They took the field Midian, as the LORD commanded Moses, and slew every male $\cdots$ The Israelites took the women and children of the Midianites captive, and seized as booty all their beasts, all their herds, and all their wealth. And they destroyed by fire all the towns in which they were settled, and their encampments $\cdots$ Moses said to them," You have spared every female! $\cdots$ Now, therefore, slay every male among the children, and slay every woman who has known a man carnally $\cdots$ ” (Numbers 31:1-2, 7, 9-11, 15, 17).

These and other similar passages have convinced many followers of the Bible that it was written by fallible, ancient and superstitious people who may have been God-inspired but who could not avoid inserting many of their own personal beliefs ${ }^{4}$. If God is really all-good, just and merciful, it would seem that many of these passages are not God's words, but rather are the words of mortal men. As such, in these instances the Bible should not be taken literally, nor viewed as infallible.

It is also worth considering how the Bible's views on women are anything but enlightened. The Bible allows for men to take multiple wives, but no such right was accorded women. If a man seduces a virgin, it is considered a property offense against her father, not an offense against her (Exodus 22:16-17). Women are not allowed to become priests (Leviticus). To give birth to a girl was twice as polluting as was giving birth to a boy (Leviticus 12:1-5). In fact, a child from one month to five years old was worth five shekels of silver if a boy, but only three shekels of silver if a girl—60\% the worth or value of a boy (Leviticus 27:6). Women were not even considered worthy to be included in the census (Numbers 3:15). If a man dies, his son inherits his estate, and his daughter gets nothing. She will inherit only if there is no son (Numbers 27:8-11). A victorious soldier can force a woman captive to marry him without regard to her wishes (Deuteronomy 21:10-13). Divorce can be initiated only by the husband, not the wife (Deuteronomy 24:1).

Here are several passages from the Old Testament which further demonstrate the general attitude toward women-specifically that women are not equal to men:

And to the woman He said "I will make most severe your pangs in childbearing. In pain you shall bear children. Yet your urge shall be for your husband. And he shall rule over you (Genesis 3:16).

When a man sells his daughter as a slave, she shall not be freed as male slaves are (Exodus 21:7).

When a man explicitly vows to the Lord the equivalent of a human being, the following scale will apply: If it is a male from 20 to 60 years of age, the equivalent is 50 shekels of silver by the sanctuary weight; if it is a female, the equivalent is 30 shekels. If the age is from 5 years to 20 years, the equivalent is 20 shekels for a male and 10 shekels for a female (Leviticus 27:2-5).

I think it is worthwhile to close with several passages from Corinthians to see that New Testament is not immune from these same attitudes.

But I want you to know that Christ is the head of every man, and the man is the head of every woman $\cdots$ (1 Corinthians 11:3).

A man, in fact, should not cover his head, because he is God's image and glory, but woman is man's glory.

For man did not come from woman, but woman came from man; and man was not created for woman, but woman for man (1 Corinthians 11:7-9).

${ }^{4}$ See Dawkins (2008) chapter 7, pp. 268-316. Dawkins gives us several biblical examples of God's immorality. For example, God saved only Noah's family from the flood, thus killing all the rest of humanity without targeting the sinners and saving those who were relatively moral; God turned Lot's wife into salt for merely looking over her shoulder at the destruction of Sodom and Gomorrah; and God would only guarantee Jephthah's victory if he would agree to sacrifice the first person he saw when returning home after victory-who happened to be Jephthah's innocent daughter who was his only child. 
As in all the churches of the saints, the women should be silent in the churches, for they are not permitted to speak, but should be submissive, as the law says. And if they want to learn something, they should ask their own husbands at home, for it is disgraceful for a woman to speak in the church meeting (1 Corinthians 14:33-35).

Indeed, the Old and New Testaments treat women as possessions or second class citizens who are clearly valued less than a man. As such, it is amazing that any modern day woman would take these passages at face value as the literal word of an all-good and fair God. It seems to make more sense to view these passages, at most, as proper for their time, but not to be taken and practiced literally today.

\section{Conclusion}

In this article I have given five reasons for why the Bible cannot be taken literally. The person who claims to take the Bible literally does not understand that words require interpretation, particularly when general rules are applied to specific situations; they do not grasp that they are already reading the interpretation of a translator; they do not realize that many general rules have unstated exceptions; they do not see that many biblical passages make no sense unless you interpret them as other than literal; and they have not noticed that there are contradictions in the Bible-which means that if one passage were capable of being taken literally then the contrary or competing passage could not be.

Furthermore, the biblical literalist who accepts the words of the Bible over accepted and well-supported scientific data and conclusions or over recent archaeological and historical findings has not taken care to research and fairly assess the evidence. Lastly, the literalist has chosen to ignore the numerous biblical passages which violate contemporary moral standards.

In view of these points, it is not surprising that many of those who claim to take the Bible literally do not realize they actually do not do so. Rather, they pick and choose which biblical passages they will follow. Barr sums it up this way:

In any case, as I have repeatedly argued, fundamentalists do not in fact follow a consistent literalism but are selectively literal, handling some passages in a literal way but ignoring the literality of others, according as their own religious position requires (Barr, 1989: p. 426, endnote 3).

If people understood the points raised here, they would be less self-righteous because they would acknowledge that their understanding of biblical passages was not necessarily the correct or only one. Accordingly they would be more tolerant toward the religious beliefs of others, whether those others were Catholic, Protestant, Methodist, Jewish, Muslim, Hindu, Buddhist, Taoist, or, I would hope, even agnostic or atheist. I fear that if the world does not learn the lesson of this article, we are destined to continue intolerance towards others whose religious beliefs are different than our own.

\section{References}

Barr, J. (1989). Literality. Faith and Philosophy, 6, 412-428.

Benner, J. (2007). The Living Words (Vol. 1, pp. 28-29). College Station: Virtualbookworm Publishing, Inc.

Chicago Statement (1997). The Chicago Statement on Biblical Inerrancy. http://www.spurgeon.org/ phil/creeds/chicago.htm

Coleman, J. (1982). Negative and Positive Positivism. In J. Feinberg, J. Coleman, \& C. Kutz (Eds.), Philosophy of Law (9th ed., pp. 123-140). Boston: Wadsworth, Cengage Learning.

Colless, B. (2013). The Empire of Sargon.

Dawkins, R. (2006). The God Delusion (pp. 268-316, 2008 ed.). New York: First Mariner Books, Houghton Mifflin Company.

Finkelstein, I., \& Silberman, N. (2001). The Bible Unearthed (p. 60). New York: Free Press.

Gannon, M. (2013). 6 Miracle Birth Stories beyond Jesus. Live Science.

http://www.livescience.com/42187-miracle-birth-stories-beyond-jesus.html

Holman Christian Standard Bible (1999). Nashville: Holman Bible Publishers.

Jones, J. (2011). In U.S., 3 in 10 Say They Take the Bible Literally. Gallup.

http://www.gallup.com/poll/148427/Say-Bible-Literally.aspx 
Murray, M. (2010). The Atheist's Primer. Ontario: Broadview Press.

Plaut, W. (1981). The Torah: A Modern Commentary. New York: Union of American Hebrew Congregations.

Pope John Paul II (1992 \& 1996). L’Osservatore Romano. Weekly Edition in English. In M. Rea, \& L. Pojman (Eds.), Philosophy of Religion: An Anthology (7th ed., pp. 502-507). Stamford: Cengage Learning.

Sartre, J. P. (1949). Existentialism Is a Humanism. In R. Solomon (Ed.), Existentialism (2nd ed., pp. 212-213). Oxford: Oxford University Press.

Wikipedia (2014) Global Biodiversity. http://en.wikipedia.org/wiki/Global_Biodiversity

Wittgenstein, L. (1953). Philosophical Investigations. In L. Pojman (Ed.), Ch. 36. Classics of Philosophy, Volume II: Modern and Contemporary (pp. 1156-1164). New York: Oxford University Press. 
Scientific Research Publishing (SCIRP) is one of the largest Open Access journal publishers. It is currently publishing more than 200 open access, online, peer-reviewed journals covering a wide range of academic disciplines. SCIRP serves the worldwide academic communities and contributes to the progress and application of science with its publication.

Other selected journals from SCIRP are listed as below. Submit your manuscript to us via either submit@scirp.org or Online Submission Portal.
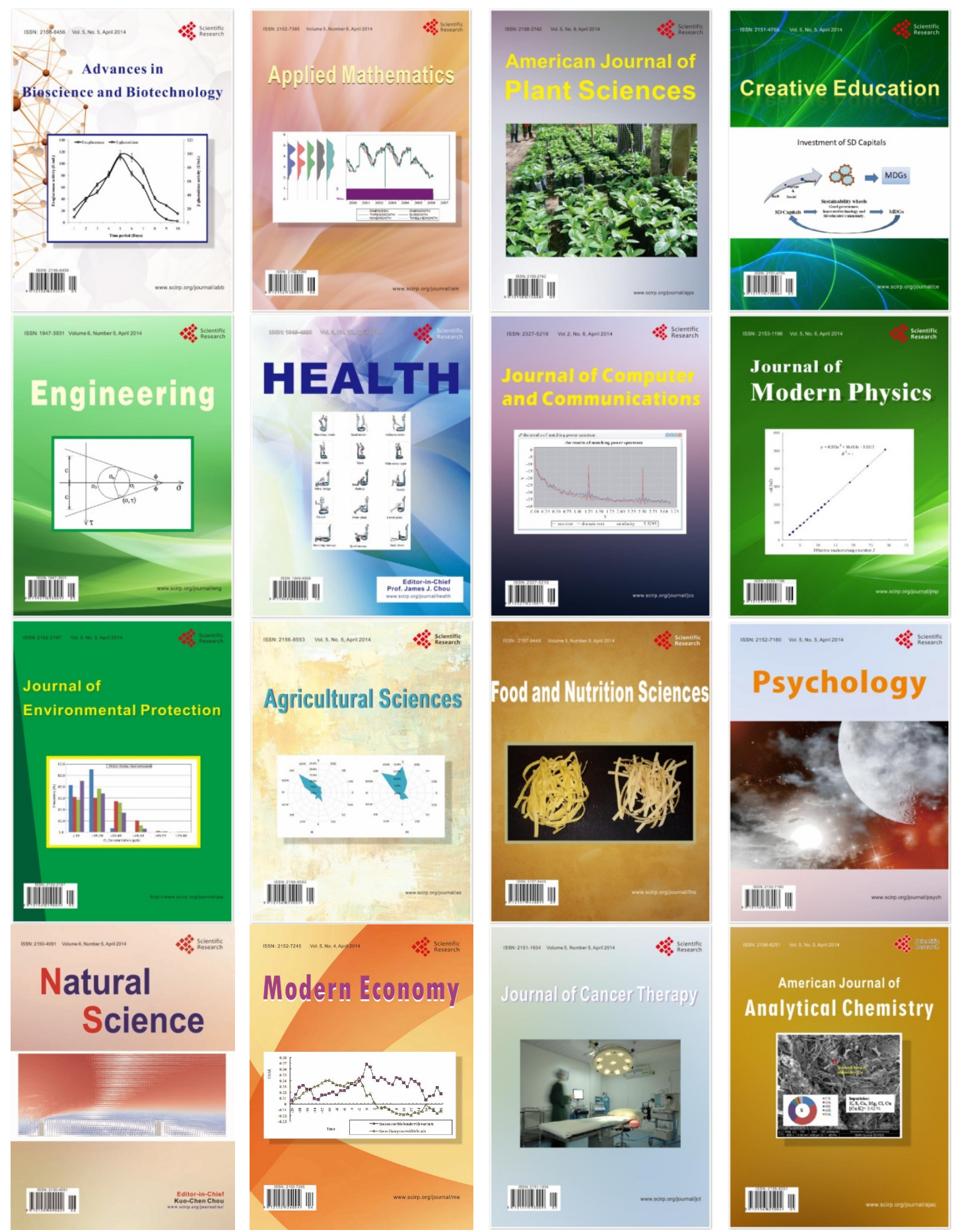